\section{BALD EAGLE RECORDS FROM THE CHURCHILL RIVER AREA}

by Peter Whitehead,

Historic Trails Canoe Club, Regina

During our annual club trip for 1964 we sighted a total of 20 Bald Eagles. Leaving Nemeiben Lake (NW of La Ronge) on June 27, our route took us through Head, Clam, Morning, Gull, Besnard, Black Bear Island, Trout, and Nipeu lakes to Missinipi and Otter lakes. We completed the trip on July 4, having covered a distance of 104 miles. The eagles were widely distributed. Single sightings were made on Clam, Triveet, Gull, and Stack lakes. On Trout, Mountney, and Nipeu we sighted two on each lake. On Black Bear Island lake we saw four, and on Besnard Lake six. A single nest was sighted at the tip of a spruce on the shore above muskeg between Triveet and Morning lakes. With one exception (an immature bird) the eagles were very shy, flying away when we approached to within 300 yards. The quiet waters immediately above and below rapids appeared to be their preferred habitat. This was also noticed on our previous trips. Incidentally, our sightings of eagles have all been casual. No attempt was made to locate birds or nests using binoculars en route.

\section{LATE NESTING OF A GRAY PARTRIDGE}

by Victor Schmidt, Melville

On September 21, 1962, I was surprised to come across a female Gray Partridge (Perdix perdix) with a brood of eight downy chicks, not more than three days old, in a stubble field six miles south of Melville. I took one of the young and have it mounted in my collection of local birds. I wish to thank Gary Anweiler for pointing out to me the very late date of this event, which must be one of the latest nestings on record for this species, and for urging me to record the data.

\section{NEST RECORDS DESIRED}

Now that the 1964 bird nesting season is past we would like to receive your Prairie Nest Records Scheme cards as soon as possible. Please send to: Prairie Nest Records Scheme c/o Robert R. Taylor, University of Saskatchewan, Regina Campus, Regina, Sask.

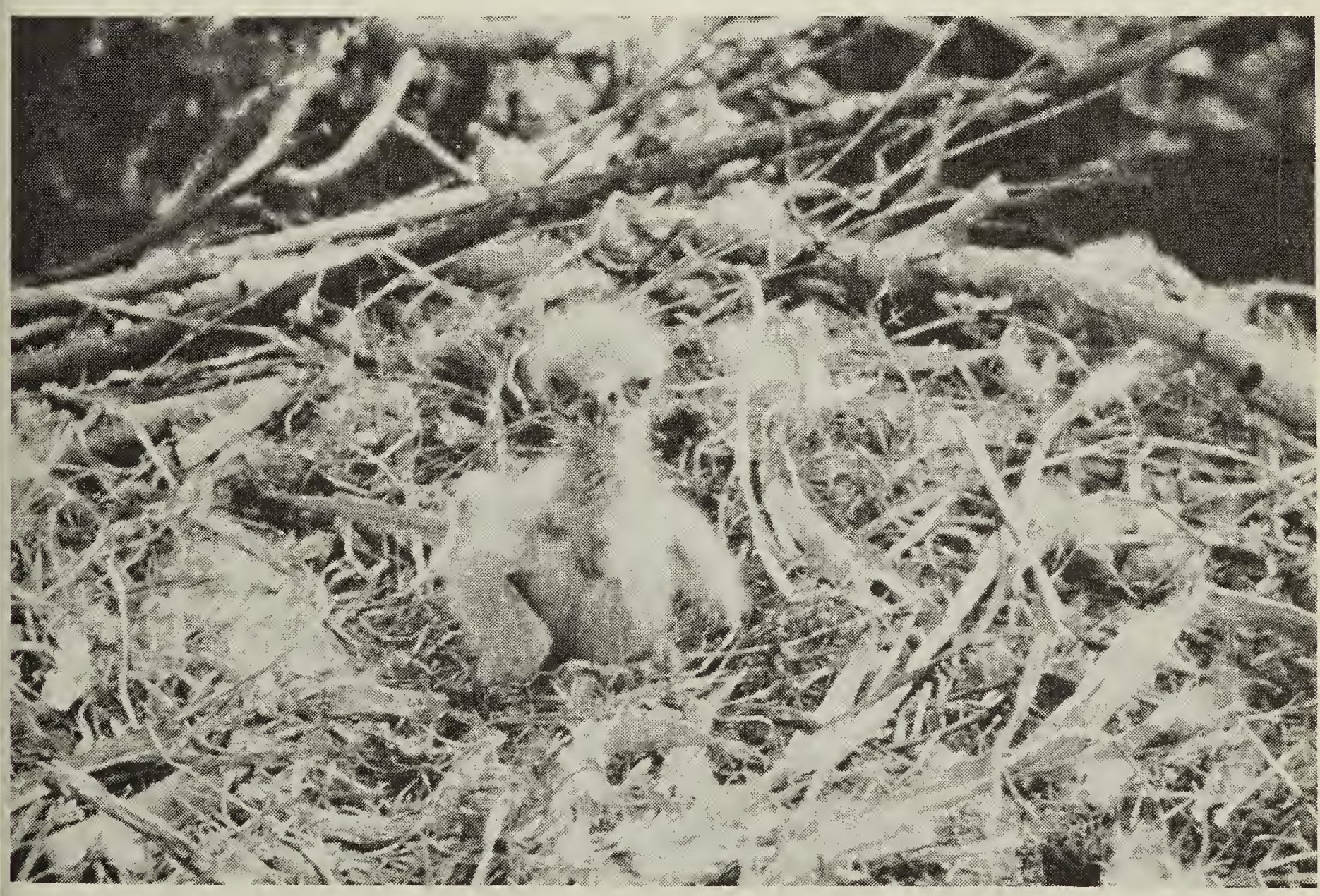

Photo from color transparency by Pat Kerr.

Newly-hatched Bald Eagle, Johnston Island, Lake Athabasca, June 30, 1961. 